Assiut University web-site: $\underline{w w w . a u n . e d u . e g}$

\title{
PREVALENCE OF CAMPYLOBACTER SPP. AND ITS PATHOGENIC GENES IN POULTRY MEAT, HUMAN AND ENVIRONMENT IN ASWAN, UPPER EGYPT
}

\author{
MOHAMED KARMI \\ Department of Food Hygiene, Faculty of Veterinary Medicine, Aswan \\ University, 81528 Aswan, Egypt
}

Received: 12 March 2019; Accepted: 9 April 2019

\begin{abstract}
A total of 250 samples including 100 samples from chicken meat, 75 samples human diarrhea, 75 samples from environment were collected from Aswan, Egypt. All samples were bacteriologically and biochemically examined for isolation, identification and differentiation of campylobacter spp., multiplex PCR detection of 23S rRNA, hipO, glyA gene for identification and differentiation of campylobacter spp. and detection of some pathogenic virulence genes include Iam, $c d t B$ and $c a d F$ genes. Prevalence of campylobacter in chicken meat, human diarrhea and environmental samples by conventional methods were $32 \%, 14.7 \%$ and $13.3 \%$, respectively. Prevalence of campylobacter in chicken meat, human diarrhea and environmental samples by mPCR were $6 \%, 5.33 \%$ and $4 \%$, respectively. About $64.3 \%, 21.4 \%$ and 14.3 of examined samples were Campylobacter jejuni, Campylobacter coli and mixed culture, respectively. Most positive samples contain high prevalence of pathogenic virulence genes. Poultry meat and environment could be a dangerous source for pathogenic campylobacter for human. Most campylobacter isolates have a lot of pathogenic genes which increase the invasiveness and pathogenicity of Campylobacter.
\end{abstract}

Key words: Chicken meat, Campylobacter jejuni, Campylobacter coli, pathogenic genes.

\section{INTRODUCTION}

Campylobacter is the most common cause of gastroenteritis worldwide especially in children (Ruiz-Palacios, 2007, Kaakoush et al., 2015), C. jejuni infection frequently causes an acute enteritis with diarrhea, malaise, fever and abdominal pain, vomiting and/or bloody diarrhea specific for the more sever end of the disease spectrum and may affected by the host susceptibility and/or infective dose (Gillespie et al., 2006). Campylobacter enteritis signs can lasts for more than a year and may contribute to post-dysenteric irritable bowel syndrome (PD-IBS) (Spiller et al., 2000) and may causes Guillain-Barre Syndrome (GBS) during the subsequent 2-month period post infection (Tam et al., 2006). GuillainBarre Syndrome (GBS) and Miller-Fisher Syndrome (MFS) are related to prior infection by $C$. jejuni in up to $40 \%$ of cases (Dingle et al., 2001).

The majority of outbreaks of acute campylobacteriosis in human worldwide were associated with consumption of chicken and chicken meat products (Corry and Atabay, 2001, Friedman

Corresponding author: Dr. MOHAMED KARMI

E-mail address: karmy99@yahoo.com

Present address: Department of Food Hygiene, Faculty of Veterinary Medicine, Aswan University, 81528 Aswan, Egypt et al., 2004) also, contact with cattle, consumption of beef and milk were responsible for more than $90 \%$ of all sporadic human cases. Other sources such as sheep, contact with wild birds, contaminated water and pet animals were contribute for human infection but in much lesser extent (Wilson et al., 2008). The use of the same cutting board for chicken meat and salad without intermediate cleaning, spreading of pathogens via the kitchen environment and contaminated tools and equipments may causes crosscontamination more than the risk associated with undercooking of poultry meat (Luber, 2009). Drinking water may conform the common reservoir linking infection between humans and animals, including poultry and wild birds (Kapperud et al., 2003). Poultry meat and its products are the most implicated food and the most significant risk factor for acquiring infection in human campylobacteriosis. Genotyping with multilocus sequence typing (MLST) and relatedness study of large number samples of $C$. jejuni isolated from humans and broilers was carried out, all results of source attribution analysis confirmed the strong linkage between broiler $C$. jejuni and human cases (Griekspoor et al., 2015).

About 35 virulence genes were discovered in campylobacter isolates using PCR testing, include those involved in motility, chemotaxis, cell adhesion, invasion, cytotoxin production, capsule, multidrug and bile resistance, stress response/survival and the 
iron uptake system, there was no discernible difference in the virulence profiles of human and poultry isolates (Koolman et al., 2015). Several authors reported that some bacterial factors are more essential for the pathogenesis of campylobacter, including the motility and adherence of bacteria to intestinal mucosa, capability to invade enterocytes and toxin production (Datta et al., 2003). One of these virulence markers is the cadF gene, which encodes a $37 \mathrm{KDa}$ protein belonging to the group of outer membrane proteins (OMPs) that functions as an adhesion protein responsible for certain steps of invasion (Konkel et al., 1999). Another interesting region, designated an invasion-associated marker (iam), has been identified in some $C$. jejuni and $C$. coli strains (Carvalho et al., 2001). CDT is composed of three subunits designated CDTs A, B and C. The B subunit targets the eukaryotic DNA and triggers a signaling pathway involving different protein kinases which results in a cell block before entering into mitosis. Until now, the individual role of the $\mathrm{A}$ and $\mathrm{C}$ subunits has not been totally elucidated. Its exact role in pathogenesis is not yet clear, but possible actions include inhibition of epithelial cell proliferation, apoptosis of immune cells and inhibition of a fibrotic response (Ceelen et al., 2006). Different distribution of genetic markers between human and chicken isolates indicates that some campylobacter infections in children may have additional sources other than contaminated chicken meat (Rozynek et al., 2005).

\section{MATERIALS AND METHODS}

\section{Samples}

A total of 250 samples including 100 samples from chicken meat (fresh chicken, frozen chicken and chicken meat products which include chicken luncheon, nuggets, pane, frozen liver and giblets), 75 samples human diarrhea (from hospitals and medical laboratories), 75 samples from environment (water, poultry slaughter house, meat shops, supermarkets, hospital's kitchens and restaurants kitchens) from Aswan, Egypt were collected. Sampling box containing ice pads was used for carrying the samples maintaining low temperature from market to laboratory in the faculty of veterinary medicine, Aswan University. Samples were preserved in sterile polyethylene bags in the refrigerator. Twenty five grams of each chicken meat sample were aseptically transferred to sterile stomacher bag containing $225 \mathrm{ml}$ Bolton broth with 5\% lysed horse blood and antibiotic supplement. The bag content was homogenized using a Stomacher $₫ 400$ Circulator (Seward Ltd., UK) for 1 minute (FDA et al., 1998). Human diarrheal samples were collected in clean sterile containers. Environmental samples were collected by swabbing and the water samples collected in clean sterile bottles then concentrated by centrifugation at $20000 \mathrm{rpm}$ for 10 minutes, the pellet was re-suspended in Bolton broth (Fricker and Park, 1989).

\section{Isolation and Identification}

Aseptically transfer 25 grams of each chicken sample to a sterile $250 \mathrm{ml}$ flask and incubated for 4 hours at $37^{\circ} \mathrm{C}$, followed by further incubation at $42^{\circ} \mathrm{C} / 48$ hours under micro-aerophilic condition (5\% oxygen, $10 \%$ carbon dioxide and $85 \%$ nitrogen). Also, each environmental swab was immersed into sterile flasks containing $10 \mathrm{ml}$ of Bolton broth (FDA et al., 1998). Loopful $(10 \mu \mathrm{l})$ was taken from each Bolton broth enrichment culture after 48 hours and streaked on Charcoal Cefoperazone Deoxycholate Modified Agar Base (mCCDA) (Oxoid, Code: CM0739) selective solid medium with selective supplement, the culture plates were incubated micro-aerobically in a microaerobic atmosphere using anaerobic jar and campylobacter gas generating kits at $42^{\circ} \mathrm{C}$ for 48 hours (Bolton et al., 1984). Diarrheal and water samples were inoculated directly on mCCDA (Maher et al., 2003). Positive colonies are grayish, flat and moistened with tendency to spread and may have a metal sheen. Positive strains were confirmed with Gram's staining, oxidase, catalase, hippurate hydrolysis, Analytical Profile Index (API) Campy and other biochemical tests.

\section{Genetic Characterization}

DNA extraction was carried out by using boiling method; DNA was prepared by the whole-cell procedure. Each DNA template was prepared by using approximately half a loopful of culture transferred to $1 \mathrm{ml}$ of brain heart infusion broth (Oxoid, Code: CM1135). The optimized whole-cell DNA preparations from all campylobacter species were further diluted 1:500 in distilled water and were heated at $100^{\circ} \mathrm{C}$ for 10 minutes. A five $\mu l$ aliquot was directly used as a template for PCR amplification (Shah et al., 2009). Primer sequences were used as forward and reverse for $23 S \mathrm{rRNA}$, hipO, glyA, cadF, $c d t B$ and iam genes used for identification of Campylobacter species and for pathogenic genes (Table). Multiplex PCR amplification of Campylobacter species genes (23S rRNA, hipO, glyA) and the second multiplex PCR for amplification of pathogenic genes $(c a d F, c d t B$, iam). Each reaction consists of $2.5 \mu \mathrm{l}$ of $10 \mathrm{x}$ buffer, $2.5 \mu 1$ master mix, 2.5 $\mu 1 \mathrm{Taq}$ polymerase, $1 \mu \mathrm{l}$ each primer, $0.5 \mu \mathrm{l}$ DNA template and nuclease free water till $25 \mu$ l volume. Thermacycler (Eppendorf, Germany) was used with initial denaturation step at 95 for 6 minutes followed by 30 cycles (denaturation at $95^{\circ} \mathrm{C}$ for 0.5 minute, annealing at $59^{\circ} \mathrm{C}$ for 0.5 minute and extension at $72^{\circ} \mathrm{C}$ for 0.5 minute for species genes) (Wang et al., 2002), (denaturation at $94^{\circ} \mathrm{C}$ for 1 minute, annealing at $55^{\circ} \mathrm{C}$ for 1 minute and extension at $72^{\circ} \mathrm{C}$ for 1 minute for pathogenic genes) ending with final extension at $72^{\circ} \mathrm{C}$ for 7 minute. Amplified products were analyzed by $1.5 \%$ agarose gel electrophoresis stained with ethidium bromide and visualized on UV transilluminator (Andrzejewska et al., 2011). 


\section{RESULTS}

Prevalence of campylobacter in chicken meat, human diarrhea and environmental samples were $32 \%$, $14.7 \%$ and $13.3 \%$, respectively. Results showed that prevalence rates were $50 \%$ for fresh chicken carcasses and $12.5 \%$ for frozen chicken carcasses. Prevalence rates of human diarrheal were $17.5 \%$ in children and $11.4 \%$ in adults while these rates were $18.75 \%$ in males and $11.62 \%$ in females. Prevalence rates in environmental samples were $44.4 \%$ in slaughter houses, $40 \%$ in restaurant's kitchens while poultry meat shops, supermarkets, hospital`s kitchens and tape water were free from campylobacter. Multiplex PCR analysis of $23 S$ rRNA gene to identify campylobacter species of positive isolates revealed lower prevalence rates which were $6 \%$ for chicken meat, $5.3 \%$ for human diarrhea and $4 \%$ for environmental samples. Genetic analysis of positive isolates for differentiation of campylobacter species through detection of hip $O$ and glyA genes revealed that $64.3 \%$ were Campylobacter jejuni, $21.4 \%$ were Campylobacter coli and $14.3 \%$ were mixed culture. Prevalence of Campylobacter jejuni were $83.3 \%$, $50 \%$ and $66.6 \%$ and of Campylobacter coli were $16.7 \%, 50 \%$ and $0 \%$ in chicken meat, human diarrhea and environmental isolates, respectively. Prevalence of virulence genes, Iam, $c d t B$ and $c a d F$ genes in all examined samples were $61.5 \%, 69.2 \%$ and $84.6 \%$, respectively. Prevalence of $c a d F, c d t B$ and Iam genes presence in Campylobacter jejuni isolates were $100 \%$, $77.8 \%$ and $55.5 \%$, respectively, while in Campylobacter coli were $33.3 \%, 33.3 \%$ and $66.6 \%$, respectively.

Table 1: Prevalence of campylobacter species in chicken meat, human diarrhea and environmental samples.

\begin{tabular}{ccccccc}
\hline \multirow{2}{*}{ Samples } & \multicolumn{3}{l}{ Prevalence of Campylobacter } & \multicolumn{2}{c}{ Percentage of Campylobacter species } \\
\cline { 2 - 5 } & No. & \multicolumn{2}{c}{$\%$} & \multirow{2}{*}{ C. jejuni } & C. coli \\
\cline { 2 - 5 } & & Classic & PCR & & \\
\hline Chicken meat & 100 & 32 & 6 & 83.3 & 50.7 \\
\hline Human diarrhea & 75 & 14.7 & 5.3 & 50 & 0 \\
\hline Environmental samples & 75 & 13.3 & 4 & 66.6 & 50 \\
\hline
\end{tabular}

Table 2: Prevalence of campylobacter virulence genes in examined samples.

\begin{tabular}{ccccc}
\hline \multirow{2}{*}{ Gene } & \multicolumn{2}{c}{ Prevalence } & C. jejuni & C. Coli \\
\cline { 2 - 4 } & No. & $\%$ & 100 & 33.3 \\
\hline Iam & 250 & 61.5 & 77.8 & 33.3 \\
\hline$c d t \mathrm{~B}$ & 250 & 69.2 & 55.5 & 66.6 \\
\hline
\end{tabular}

Table 3: Primer sequences of campylobacter species genes and pathogenic genes.

\begin{tabular}{|c|c|c|c|c|}
\hline Gene & Primer & Oligonucleotide sequence $\left(5^{\prime} \rightarrow 3^{\prime}\right)$ & $\begin{array}{l}\text { Product } \\
\text { size(bp) }\end{array}$ & References \\
\hline \multirow{2}{*}{$\begin{array}{l}\text { 23S rRNA } \\
\text { (C. spp.) }\end{array}$} & 23S rRNA $(\mathrm{F})$ & 5' TATACCGGTAAGGAGTGCTGGAG '3 & \multirow[t]{2}{*}{650} & \multirow{2}{*}{$\begin{array}{l}\text { (Wang et al., } \\
\text { 2002) }\end{array}$} \\
\hline & $23 \mathrm{~S}$ rRNA $(\mathrm{R})$ & 5' ATCAATTAACCTTCGAGCACCG '3 & & \\
\hline \multirow{2}{*}{$\begin{array}{l}\text { hipO } \\
\text { (C. jejuni) }\end{array}$} & hipO $(\mathrm{F})$ & 5' ACTTCTTTATTGCTTGCTGC '3 & \multirow[t]{2}{*}{323} & \multirow{2}{*}{$\begin{array}{l}\text { (Wang et al., } \\
\text { 2002) }\end{array}$} \\
\hline & $\operatorname{hipO}(\mathrm{R})$ & 5' GCCACAACAAGTAAAGAAGC '3 & & \\
\hline \multirow{2}{*}{$\begin{array}{c}\text { glyA } \\
\text { (C. coli) }\end{array}$} & glyA (F) & 5' GTAAAACCAAAGCTTATCGTG '3 & \multirow[t]{2}{*}{126} & \multirow{2}{*}{$\begin{array}{l}\text { (Wang et al., } \\
\text { 2002) }\end{array}$} \\
\hline & glyA (R) & 5' TCCAGCAATGTGTGCAATG '3 & & \\
\hline \multirow{2}{*}{ cadF } & $\operatorname{cadF}(\mathrm{F})$ & 5' TGGAGGGTAATTTAGATATG '3 & \multirow[t]{2}{*}{400} & \multirow{2}{*}{$\begin{array}{c}\text { (Konkel et al., } \\
\text { 1999a) }\end{array}$} \\
\hline & $\operatorname{cadF}(\mathrm{R})$ & 5' CTAATACCTAAAGTTGAAAC '3 & & \\
\hline \multirow{2}{*}{$\operatorname{ctdB}$} & $\operatorname{ctdB}(\mathrm{F})$ & 5' GTTAAAATCCCCTGCTATCAACCA '3 & \multirow[t]{2}{*}{495} & \multirow{2}{*}{$\begin{array}{c}\text { (Ripabelli et al., } \\
\text { 2010) }\end{array}$} \\
\hline & $\operatorname{ctdB}(\mathrm{R})$ & 5' GTTGGCACTTGGAATTTGCAAGGC'3 & & \\
\hline \multirow{2}{*}{ iam } & $\operatorname{iam}(\mathrm{F})$ & 5' GCGCAAAATATTATCACCC '3 & \multirow[t]{2}{*}{518} & \multirow{2}{*}{$\begin{array}{c}\text { (Carvalho et al., } \\
\text { 2001) }\end{array}$} \\
\hline & $\operatorname{Iam}(\mathrm{R})$ & 5' TTCACGACTACTATGCGG '3 & & \\
\hline
\end{tabular}




\section{DISCUSSION}

In this study, the prevalence of campylobacter in chicken meat samples was $32 \%$ which is similar to that found in Gauteng, South Africa, 32.3\% (Van Nierop et al., 2005) and lower than rates in Spain in which campylobacter isolated with percentage of 49.5\% from chicken meat samples (Dominguez et al., 2002). Poultry can be contaminated from a variety of sources on farms and the contaminants are spread during processing, scalding, defeathering, evisceration and giblet operations are major points of spread, further spread can occur during handling in markets and kitchens. Insufficient thermal processing or cooking allows survival, Improper handling of cooked chicken frequently results in cross contamination from previously handled raw carcasses and parts (Bryan and Doyle, 1995). Prevalence of campylobacter in fresh chicken carcasses and in frozen carcasses was $50 \%$ and $12.5 \%$, respectively. These rates are lower than results of fresh chickens sold in Ontario and Ohio which are $62 \%$ and 54\%, respectively, (Park et al., 1981) and 64\% in Sapporo, Hokkaido, Japan (Sallam, 2007), lower rates, 39.2\% was recorded (Sproston et al., 2014), also, it is noticed that prevalence of campylobacter in fresh chickens was higher than that of frozen ones, reduction in positive samples in frozen chickens may be due to killing of campylobacter spp. or sub-lethal injury with or without reduction in viable counts under investigated storage temperatures which may indicates the ability of campylobacter to survive in chicken meat stored under refrigerated and frozen conditions (Eideh and Al-Qadiri, 2011), also, may be due to oxidative stress contribute to the freeze-thaw induced killing of campylobacter (Stead and Park, 2000). Prevalence of campylobacter in human diarrheal samples was $14.7 \%$ which are higher than results of Bangkok and its suburb in Thailand, 3\% (Samosornsuk et al., 2015), and results of northern region of India, 2.6\% (Vaishnavi et al., 2015) and lower than results obtained in Indonesia which was $79.5 \%$ (Pagaya et al., 2015) and that obtained in Pakistan which was 30\% (Guhar et al., 2015), variations of rates in various parts of the world may be due to the varying standards and styles of living conditions, water supply and feeding habits. Rate of campylobacter in children was $17.5 \%$ which was lower than results in Egypt which was 35\% (Barakat et al., 2015), higher than results of India which was $10 \%$ (Salim et al., 2014) and similar to results of northern Thailand which was $18 \%$ (Padungtod and Kaneene, 2005). Rate in adults was $11.4 \%$ which was higher than in northern Thailand which was $5 \%$ (Padungtod and Kaneene, 2005), prevalence in children was higher than that in adults may be due to lower immunity in children and lower standard of personal hygiene in contrast to adults, in older ages, most infections by campylobacter are mild or asymptomatic, probably because of immunity that may follow frequent exposure to contaminated food or water (Havelaar et al., 2009). Campylobacter infections were more common in males, $18.7 \%$, than in females, $11.6 \%$, and this may be due to that males are more exposed to infection than females, also, males eating food outside home more than females (Sadkowska-Todys and Hucharczyk, 2012). Prevalence of campylobacter in environmental samples was $13.3 \%$ which are lower than results of Israel which was $38.7 \%$ from environmental swabs and $100 \%$ from washing water (Rogol et al., 1985) and higher than results of Turin, northern Italy which was $0 \%$ for swabs (Bellio et al., 2014) and in Sao Paulo, Brazil which was $4.9 \%$ in abattoirs (Cortez et al., 2006). Prevalence rates in environmental samples were $44.4 \%$ in slaughter houses, $40 \%$ in restaurant's kitchens while poultry meat shops, supermarkets, hospital's kitchens and tape water were free from campylobacter. These results indicate higher rates of contamination in slaughter houses and restaurants that may attributed to low level of hygiene and cleanliness, high incidence of cross contamination from other birds and from use of equipments and utensils, low personal hygiene of workers (Tang et al., 2011). Transfer of campylobacter from naturally contaminated raw chicken products to cooked chicken products via cutting board occurred and that both $C$. jejuni and $C$. coli are able to transfer (Guyard-Nicodeme et al., 2013). There is no campylobacter found in tape water which is similar to results obtained in Finland (Hänninen et al., 2003), this may be due to well chlorination of water (Moore et al., 1996). Results showed high proportion of $C$. jejuni relative to $C$. coli in all tested samples. Prevalence of campylobacter species in chicken meat was $83.3 \% C$. jejuni and $16.7 \% C$. coli, these findings were differ than results obtained in Yangzhou, China which was $45.5 \%$ C. jejuni and $30.9 \%$ C. coli (Huang et al., 2016) and closely similar to results of Sao Paulo, Brazil which was $91.6 \%$ C. jejuni and $8.3 \% C$. coli (Carvalho et al., 2013). Prevalence of campylobacter species in human samples was $50 \% C$. jejuni and $50 \% C$. coli which are closely similar to results of Thailand which was $58 \%$ C. jejuni and $40 \%$ C. coli (Samosornuk et al., 2015) and differs than results of Kayseri, Turkey which was $84 \%$ C. jejuni and $13 \%$ C. coli and 5\% other species (Kayman et al., 2013) and fifers than results of north Lebanon which was $10 \%$ C. jejuni, $10 \%$ C. coli, $20 \%$ mixed culture and $60 \%$ other species (Dabboussi et al., 2012). Prevalence of campylobacter species in environmental samples was $66.7 \% \quad C$. jejuni and $33.3 \%$ mixed culture, this finding was differs than results of Brazil which was $93.3 \%$ C. jejuni and $6.7 \%$ C. coli from abattoir samples (Cortez et al., 2006), while in Italy was found $0 \%$ for any of Campylobacter spp. in environmental samples (Bellio et al., 2014). Genetic characterization of pathogenic genes results showed that in chicken meat samples, prevalence of Iam gene was $60 \%$ in $C$. jejuni and $100 \%$ C. coli, cdtB gene was $80 \%$ C. jejuni and $0 \%$ C. coli and cadF gene found in $100 \%$ C. jejuni and 
$0 \%$ C. coli. In human samples, prevalence of Iam, $c d t B$ and $c a d F$ genes were $100 \%$ C. jejuni and $50 \%$ $C$. coli in all samples. In environmental samples, prevalence of $c d t B$ gene was $50 \%$ in $C$. jejuni and $100 \%$ in mixed culture, $c a d F$ gene was found in $100 \%$ of samples while Iam gene was not found in C. jejuni isolates and found in $100 \%$ in mixed culture. Iam gene is responsible for invasiveness of Campylobacter species and marker potentially associated with the severity of campylobacterinduced enteritis (Carvalho et al., 2001) and this gene was prominent in $C$. coli compared to $C$. jejuni (Andrzejewska et al., 2015). cadF gene is gene of adhesion of campylobacter to fibronectin, an outer membrane protein (Monteville et al., 2003), cadF gene was found nearly in all campylobacter isolates (Rozynek et al., 2005). The cdtB gene is the toxinforming gene of campylobacter jejuni, seems to be important for cell cycle control ond induction of host cell apoptosis and recognized as a major pathogenicity-associated factor (Dasti et al., 2010), the possible actions of this toxin are firstly inhibition of epithelial cell proliferation and apoptosis allowing bacterial invasion, secondly cell cycle arrest of immune cells ensuing local immune suppression and finally inhibition of fibrotic response (Ceelen et al., 2006).CDT activity requires the function of three genes: $c d t A, c d t B$ and $c d t C$ (Lara-Tejero and Galan, 2001).

\section{CONCLUSION}

Poultry meat and poultry meat products were an important source of campylobacter infections, also, campylobacter contamination can occur through environmental sources and from human itself. Campylobacter food poisoning caused mainly by Campylobacter jejuni and to lesser extent by Campylobacter coli and other species and most of the isolates was Campylobacter jejuni. Most campylobacter isolates have pathogenic genes responsible for adhesion, invasion and cytolethal toxins production which increase the virulence and pathogenicity of the microorganism.

\section{AUTHORS' CONTRIBUTIONS}

Author performs collection, preparation, processing, and analysis of samples, isolation of bacteria, data acquisition, writing, preparation and revision of manuscript.

\section{ACKNOWLEDGEMENTS}

I thank Faculty of Veterinary Medicine, Aswan University for Financial support and Veterinarian, for his technical support and help in isolation of bacteria.

\section{REFERENCES}

Andrzejewska, M.; Klawe, J.; Szczepańska, B. and Śpica, D. (2011): Occurrence of virulence genes among Campylobacter jejuni and Campylobacter coli isolates from domestic animals and children. Polish journal of veterinary sciences 14, 207-211.

Andrzejewska, M.; Szczepańska, B.; Śpica, D. and Klawe, J.J. (2015): Trends in the occurrence and characteristics of Campylobacter jejuni and Campylobacter coli isolates from poultry meat in Northern Poland. Food Control 51, 190-194

Barakat, A.; Sobhy, M.M.; El Fadaly, H.; Rabie, N.S.; Khalifa, N.O.; Ramadan, E.S.; Kotb, M.; Girh, Z.M.A.; Sedik, D.M. and Zaki, M.S. (2015): Zoonotic Hazards of Campylobacteriosis in some areas in Egypt. Life Science Journal 12, 9-14.

Bellio, A.; Traversa, A.; Adriano, D.; Bianchi, D.M.; Colzani, A.; Gili, S.; Dondo, A.; Gallina, S.; Grattarola, C. and Maurella, C. (2014): Occurrence of thermotolerant Campylobacter in raw poultry meat, environmental and pigeon stools collected in open-air markets. Italian Journal of Food Safety 3, 157-159.

Bolton, F.J.; Hutchinson, D.N. and Coates, D. (1984): Blood-free selective medium for the isolation of Campylobacter jejuni from feces. J. Clin. Microbiol., 19, 169 - 171.

Bryan, F.L. and Doyle, M.P. (1995): Health risks and consequences of Salmonella and Campylobacter jejuni in raw poultry. Journal of Food Protection ${ }^{\circledR}$ 58, 326-344.

Carvalho, A.C.; Ruiz-Palacios, G.M.; RamosCervantes, P.; Cervantes, L.-E.; Jiang, X. and Pickering, L.K. (2001): Molecular characterization of invasive and noninvasive Campylobacter jejuni and Campylobacter coli isolates. Journal of clinical microbiology 39, 1353-1359.

Carvalho, A.F.D.; Silva, D.M.D.; Azevedo, S.S.; Piatti, R.M.; Genovez, M.E. and Scarcelli, E. (2013): Detection of CDT toxin genes in Campylobacter spp. strains isolated from broiler carcasses and vegetables in São Paulo, Brazil. Brazilian Journal of Microbiology 44, 693-699.

Ceelen, L.M.; Decostere, A.; Ducatelle, R. and Haesebrouck, F. (2006): Cytolethal distending toxin generates cell death by inducing a bottleneck in the cell cycle. Microbiological research 161, 109-120.

Corry, J. and Atabay, H. (2001): Poultry as a source of Campylobacter and related organisms. Journal of Applied Microbiology 90, 96S$114 \mathrm{~S}$.

Cortez, A.L.; Carvalho, A.C.; Scarcelli, E.; Miyashiro, S.; Vidal-Martins, A. and Bürger, 
K.P. (2006): Survey of chicken abattoir for the presence of Campylobacter jejuni and Campylobacter coli. Revista do Instituto de Medicina Tropical de São Paulo 48, 307-310.

Dabboussi, F.; Alam, S.; Mallat, H.; Hlais, S. and Hamze, M. (2012): Preliminary study on the prevalence of Campylobacter in childhood diarrhoea in north Lebanon. Eastern Mediterranean Health Journal 18, 1125-1128.

Dasti, J.I.; Tareen, A.M.; Lugert, R.; Zautner, A.E. and Groß, U. (2010): Campylobacter jejuni: a brief overview on pathogenicity-associated factors and disease-mediating mechanisms. International Journal of Medical Microbiology 300, 205-211.

Datta, S.; Niwa, H. and Itoh, K. (2003): Prevalence of 11 pathogenic genes of Campylobacter jejuni by PCR in strains isolated from humans, poultry meat and broiler and bovine faeces. Journal of medical microbiology 52, 345-348.

Dingle, K.; Van Den Braak, N.; Colles, F.; Price, L.J.; Woodward, D.L.; Rodgers, F.G.; Endtz, H.; Van Belkum, A. and Maiden, M. (2001): Sequence typing confirms that Campylobacter jejuni strains associated with Guillain-Barre and Miller-Fisher syndromes are of diverse genetic lineage, serotype, and flagella type. Journal of clinical microbiology 39, 33463349.

Dominguez, C.; Gomez, I. and Zumalacarregui, J. (2002): Prevalence of Salmonella and Campylobacter in retail chicken meat in Spain. International journal of food microbiology 72 , 165-168.

Eideh, A.A.M. and AlQadiri, H.M. (2011): Effect of refrigerated and frozen storage on the survival of Campylobacter jejuni in cooked chicken meat breast. Journal of food science 76, M17M21.

FDA, Hunt, J.M. and Abeyta, C.T.T. (1998): FDA Bacteriological Analytical Manual. Chapter 7, Campylobacter,. 8th edition (revision A), 23 pages.

Fricker, C. and Park, R. (1989): A two-year study of the distribution of 'thermophilic' campylobacters in human, environmental and food samples from the Reading area with particular reference to toxin production and heat-stable serotype. Journal of Applied Bacteriology 67, 477-490.

Friedman, C.R.; Hoekstra, R.M.; Samuel, M.; Marcus, R.; Bender, J.; Shiferaw, B.; Reddy, S.; Ahuja, S.D.; Helfrick, D.L. and Hardnett, F. (2004): Risk factors for sporadic Campylobacter infection in the United States: a case-control study in FoodNet sites. Clinical Infectious Diseases 38, S285-S296.

Gillespie, I.A.; O'Brien, S.J.; Frost, J.A.; Tam, C.; Tompkins, D.; Neal, K.R.; Syed, Q. and Farthing, M.J. (2006): Investigating vomiting and/or bloody diarrhoea in Campylobacter jejuni infection. Journal of medical microbiology 55, 741-746.

Griekspoor, P.; Engvall, E.O.; Åkerlind, B.; Olsen, B. and Waldenström, J. (2015): Genetic diversity and host associations in Campylobacter jejuni from human cases and broilers in 2000 and 2008. Veterinary Microbiology 178, 94-98.

Guhar, D.; Khan, A. and Irfan, S. (2015): Biosurveillance of infectious bacterial diarrhea in Pakistan: A retrospective study. In Applied Sciences and Technology (IBCAST), 2015 12th International Bhurban Conference on, pp. 91-92. IEEE.

Guyard-Nicodème, M.; Tresse, O.; Houard, E.; Jugiau, F.; Courtillon, C.; El Manaa, K.; Laisney, M.-J. and Chemaly, M. (2013): Characterization of Campylobacter spp. transferred from naturally contaminated chicken legs to cooked chicken slices via a cutting board. International journal of food microbiology 164, 7-14.

Hänninen, M.-L.; Haajanen, H.; Pummi, T.; Wermundsen, K.; Katila, M.-L.; Sarkkinen, H.; Miettinen, I. and Rautelin, H. (2003): Detection and typing of Campylobacter jejuni and Campylobacter coli and analysis of indicator organisms in three waterborne outbreaks in Finland. Applied and Environmental Microbiology 69, 1391-1396.

Havelaar, A.H.; van Pelt, W.; Ang, C.W.; Wagenaar, J.A.; van Putten, J.P.; Gross, U. and Newell, D.G. (2009): Immunity to Campylobacter: its role in risk assessment and epidemiology. Critical reviews in microbiology 35, 1-22.

Huang, J.; Zong, Q.; Zhao, F.; Zhu, J. and Jiao, X.-A. (2016): Quantitative surveys of Salmonella and Campylobacter on retail raw chicken in Yangzhou, China. Food Control 59, 68-73.

Kaakoush, N.O.; Castaño-Rodríguez, N.; Mitchell, H.M. and Man, S.M. (2015): Global epidemiology of Campylobacter infection. Clinical microbiology reviews 28, 687-720.

Kapperud, G.; Espeland, G.; Wahl, E.; Walde, A.; Herikstad, H.; Gustavsen, S.; Tveit, I.; Natås, O.; Bevanger, L. and Digranes, A. (2003): Factors associated with increased and decreased risk of Campylobacter infection: a prospective case-control study in Norway. American Journal of Epidemiology 158, 234242.

Kayman, T.; Abay, S. and Hizlisoy, H. (2013): Identification of Campylobacter spp. isolates with phenotypic methods and multiplex polymerase chain reaction and their antibiotic susceptibilities. Mikrobiyoloji bulteni 47, 230239.

Konkel, M.E.; Kim, B.J.; Rivera Amill, V. and Garvis, S.G. (1999): Bacterial secreted proteins are required for the internalization of Campylobacter jejuni into cultured 
mammalian cells. Molecular microbiology 32, 691-701.

Koolman, L.; Whyte, P.; Burgess, C. and Bolton, D. (2015): Distribution of Virulence-Associated Genes in a Selection of Campylobacter Isolates. Foodborne pathogens and disease 12, 424-432.

Lara-Tejero, M.A. and Galán, J.E. (2001): CdtA, $\mathrm{CdtB}$, and $\mathrm{CdtC}$ form a tripartite complex that is required for cytolethal distending toxin activity. Infection and immunity 69, 43584365.

Luber, P. (2009): Cross-contamination versus undercooking of poultry meat or eggs - which risks need to be managed first? International journal of food microbiology 134, 21-28.

Maher, M.1.; Finnegan C.; Collins, E.; Ward, B.; Carroll, C. and Cormican, M. (2003): Evaluation of culture methods and a DNA probe-based PCR assay for detection of Campylobacter species in clinical specimens of feces. J Clin Microbiol., 41(7), 2980-2986.

Monteville, M.R.; Yoon, J.E. and Konkel, M.E. (2003): Maximal adherence and invasion of INT 407 cells by Campylobacter jejuni requires the CadF outer-membrane protein and microfilament reorganization. Microbiology 149, 153-165.

Moore, J.E.; Wilson, T.S.; Wareing, D.R.; Wilson, I.G.; Humphrey, T.J. and Murphy, P.G. (1996): Occurrence of thermophilic Campylobacter spp. in foods and waters in Northern Ireland. In Campylobacters, Helicobacters, and Related Organisms, pp. 135-139. Springer.

Padungtod, P. and Kaneene, J.B. (2005): Campylobacter in food animals and humans in northern Thailand. Journal of Food Protection ${ }^{\circledR}$ 68, 2519-2526.

Pagaya, J.; Massi, M.N.; Limmon, G.V. and Natsir, $R$. (2015): Detection of flaA Virulence Genes Campylobacter jejuni, Isolated from Human Faeces and Groundwater Using PCR Method. International Journal of Current Microbiology and Applied Sciences 4, 379-387.

Park, C.; Stankiewicz, Z.; Lovett, J. and Hunt, J. (1981): Incidence of Campylobacter jejuni in fresh eviscerated whole market chickens. Canadian journal of microbiology 27, 841842.

Rogol, M.; Sechter, I.; Greenberg, Z.; Mizrachi, R.; Shtark, Y. and Alfi, S. (1985): Contamination of chicken meat and environment with various serogroups of Campylobacter jejuni/coli. International Journal of Food Microbiology 1, 271-276.

Rozynek, E.; Dzierzanowska-Fangrat, K.; Jozwiak, P.; Popowski, J.; Korsak, D. and Dzierzanowska, D. (2005): Prevalence of potential virulence markers in Polish Campylobacter jejuni and Campylobacter coliisolates obtained from hospitalized children and from chicken carcasses. Journal of medical microbiology 54, 615-619.

Ruiz-Palacios, G.M. (2007): The health burden of Campylobacter infection and the impact of antimicrobial resistance: playing chicken. Clinical Infectious Diseases 44, 701-703.

Sadkowska-Todys, M. and Kucharczyk, B. (2012): Campylobacteriosis in Poland in 2011. Przeglad epidemiologiczny 67, 9-227.

Salim, S.; Mandal, J. and Parija, S. (2014): Isolation of Campylobacter from human stool samples. Indian journal of medical microbiology 32, 35.

Sallam, K.I. (2007): Prevalence of Campylobacter in chicken and chicken by-products retailed in Sapporo area, Hokkaido, Japan. Food Control 18, 1113-1120.

Samosornsuk, W.; Asakura, M.; Yoshida, E.; Taguchi, T.; Eampokalap, B.; Chaicumpa, W. and Yamasaki, S. (2015): Isolation and characterization of Campylobacter strains from diarrheal patients in Bangkok and its suburb in Thailand. Japanese journal of infectious diseases 68, 209-215.

Shah, D.; Shringi, S.; Besser, T. and Call, D. (2009): Molecular detection of foodborne pathogens, Boca Raton: CRC Press, In Liu, D. (Ed). Taylor \& Francis group, Florida, USA, Pp., 369-389.

Spiller, R.; Jenkins, D.; Thornley, J.; Hebden, J.; Wright, T.; Skinner, M. and Neal, K. (2000): Increased rectal mucosal enteroendocrine cells, $\mathrm{T}$ lymphocytes, and increased gut permeability following acute Campylobacter enteritis and in post-dysenteric irritable bowel syndrome. Gut 47, 804-811.

Sproston, E.; Carrillo, C. and Boulter-Bitzer, J. (2014): The quantitative and qualitative recovery of Campylobacter from raw poultry using USDA and Health Canada methods. Food microbiology 44, 258-263.

Stead, D. and Park, S.F. (2000): Roles of Fe superoxide dismutase and catalase in resistance of Campylobacter coli to freezethaw stress. Applied and environmental microbiology 66, 3110-3112.

Tam, C.C.; Rodrigues, L.C.; Petersen, I.; Islam, A.; Hayward, A. and O'Brien, S.J. (2006): Incidence of Guillain-Barré syndrome among patients with Campylobacter infection: a general practice research database study. Journal of Infectious Diseases 194, 95-97.

Tang, J.Y.H.; Nishibuchi, M.; Nakaguchi, Y.; Ghazali, F.; Saleha, A. and Son, R. (2011): Transfer of Campylobacter jejuni from raw to cooked chicken via wood and plastic cutting boards. Letters in applied microbiology 52, 581-588.

Vaishnavi, C.; Singh, M.; Thakur, J.S. and Thapa, B.R. (2015): Low Prevalence of 
Campylobacteriosis in the Northern Region of India. Advances in Microbiology 5, 155.

Van Nierop, W.; Duse, A.; Marais, E.; Aithma, N.; Thothobolo, N.; Kassel, M.; Stewart, R.; Potgieter, A.; Fernandes, B. and Galpin, J. (2005): Contamination of chicken carcasses in Gauteng, South Africa, by Salmonella, Listeria monocytogenes and Campylobacter. International journal of food microbiology 99, 1-6.

Wang, G.; Clark, C.G.; Taylor, T.M.; Pucknell, C.; Barton, C.; Price, L.; Woodward, D.L. and
Rodgers, F.G. (2002): Colony multiplex PCR assay for identification and differentiation of Campylobacter jejuni, C. coli, C. lari, C. upsaliensis, and C. fetus subsp. fetus. Journal of clinical microbiology 40, 4744-4747.

Wilson, D.J.; Gabriel, E.; Leatherbarrow, A.J.; Cheesbrough, J.; Gee, S.; Bolton, E.; Fox, A.; Fearnhead, P.; Hart, C.A. and Diggle, P.J. (2008): Tracing the source of campylobacteriosis. Public Library of Science Genetics 4, e1000203.

\section{مدى انتثار ميكروب الكامبيلوباكتر و جيناته الممرضة فى لحوم الدواجن و الأنسان و البيئة فى أسوان - مصر

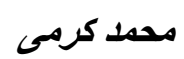

E-mail: karmy99@yahoo.com

Assiut University web-site: www.aun.edu.eg

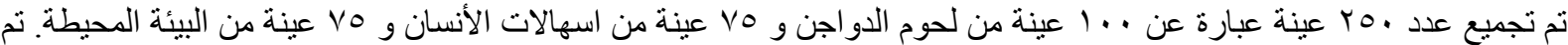

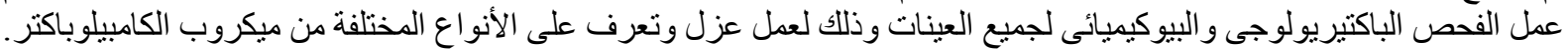

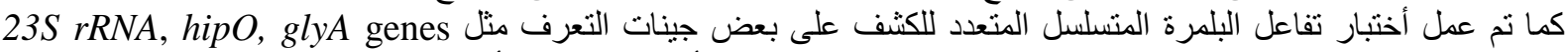

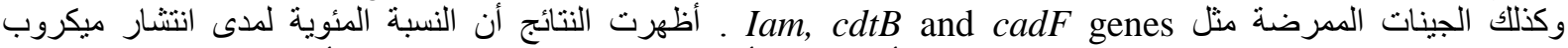

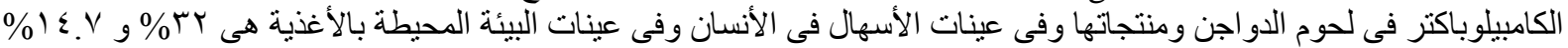

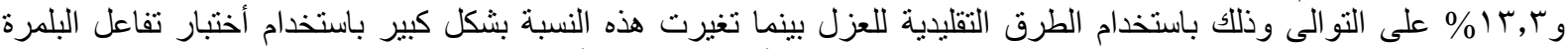

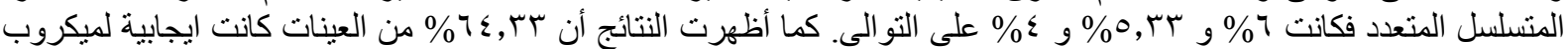

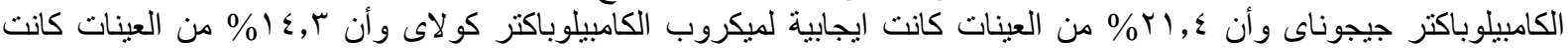

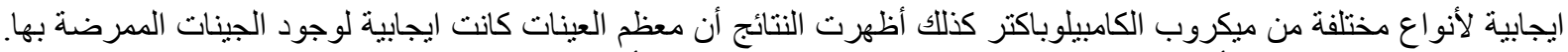

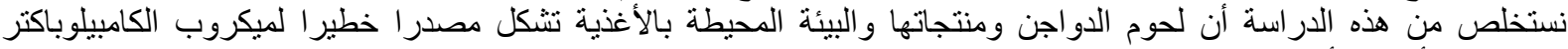
الممرض للأنسان وأن معظم هذه الميكروبات تحتوى على جينات الضر التهر اوة الخطيرة. 